DALAT UNIVERSITY JOURNAL OF SCIENCE Volume 12, Issue 1, $2022 \quad$ 20-38

\title{
PROTECTIVE BEHAVIOR AGAINST COVID-19 AMONG VIETNAMESE PEOPLE IN THE SOCIAL DISTANCING CAMPAIGN: A CROSS-SECTIONAL STUDY
}

\author{
Tu Phung Tran ${ }^{\mathrm{a}, \mathrm{b}}$, Le Vu Dinh Phi ${ }^{*}$, Diep Thanh Hoa \\ ${ }^{a}$ The Faculty of Foreign Languages, Dalat University, Lam Dong, Vietnam \\ ${ }^{b}$ School of Chinese Language and Literature, Nanjing Normal University, Jiangsu, China \\ ${ }^{c}$ The Faculty of Pedagogy, Dalat University, Lam Dong, Vietnam \\ ${ }^{d}$ School of Business, Nanjing Normal University, Jiangsu, China \\ *Corresponding author: Email: philvd@dlu.edu.vn
}

\begin{abstract}
Article history
Received: June $17^{\text {th }}, 2020$

Received in revised form: October $28^{\text {th }}, 2020 \mid$ Accepted: November $25^{\text {th }}, 2020$

Available online: February $23^{\text {rd }}, 2021$
\end{abstract}

\begin{abstract}
In the global fight against the rapid spread of COVID-19, a variety of unprecedented preventive measures have been implemented across the globe, as well as in Vietnam. How Vietnamese people respond to threats to their health and life remains unclear. For this reason, the current study aims to examine Vietnamese people's protective behavior and its factors. Based on 1,798 online survey respondents' data collected on the last three days of the nationwide social distancing campaign in mid-April, it is found that gender, knowledge of COVID-19 and preventive measures, and attitudes towards the COVID-19 prevention policies are the three main factors of participants' protective behaviors. We also find that males are less likely than females to adopt precautionary measures. People who are knowledgeable about COVID-19 may have inappropriate practices towards it. Further research is needed to examine other determinants of protective behaviors to provide more useful information for authorities, public health policy-makers, and healthcare workers to deliver the best practices to control COVID-19 in our country.
\end{abstract}

Keywords: COVID-19; Factors associated with protective behaviors; Legal policies; Social distancing policies.

DOI: http://dx.doi.org/10.37569/DalatUniversity.12.1.736(2022)

Article type: (peer-reviewed) Full-length research article

Copyright $\odot 2021$ The author(s).

Licensing: This article is licensed under a CC BY-NC 4.0 


\section{INTRODUCTION}

\subsection{COVID-19}

Coronavirus disease 2019 (or COVID-19) is a contagious disease caused by a novel coronavirus and first identified in December 2019 in Wuhan, China (Liu et al., 2020). According to the World Health Organization (WHO), this disease has a very high possibility to spread from person to person. Clinical symptoms (e.g., fever and cough) can range from mild to severe and even death. These symptoms may appear 2-14 days after exposure to the virus (Cổng thông tin điện tử của Bộ Y tế Việt Nam, 2020; World Health Organization, 2020a). Older adults and people having serious underlying medical conditions may be at higher risk for severe complications from COVID-19. In addition, according to the WHO and several studies on COVID-19, its fatality rate is around $2.3 \%$, which is much lower than SARS (9.5\%), MERS-CoV (34.3\%), and H7N9 (39.0\%) (Chen et al., 2020; Munster et al., 2020; Novel Coronavirus Pneumonia Emergency Response Epidemiology Team, 2020; World Health Organization, 2020d). Currently, COVID-19 has spread rapidly around the world. As of May $6^{\text {th }}, 2020$, it had spread to 211 countries, and globally there were 3,588,773 cases and 247,503 deaths (World Health Organization, 2020c). Obviously, the best way to prevent and slow down the spread of COVID-19 is to know more about this disease. In addition, the WHO has also declared COVID-19 as an emergency and called for collaborative efforts of all countries to reduce its communitywide spread (World Health Organization, 2020e).

\subsection{Situation during the COVID-19 epidemic in Vietnam}

Stage 1: After the Wuhan lockdown was announced on January $23^{\text {rd }}$, China was among the first countries to enter the battle against the coronavirus outbreak (Caixinwang, 2020). According to Báo Điện tử $24 \mathrm{H}$ (2020), Vietnam, a neighboring country sharing a land border of more than $1,400 \mathrm{~km}$ in length with China, also entered this battle. On February $26^{\text {th }}, 2020$, although there was no specific treatment and no vaccine yet, it could be confirmed that COVID-19 had been quite successfully brought under control by Vietnam when the first 16 cases of infection were tested negative.

Stage 2: However, when some initial cases of domestic transmission were detected on February $1^{\text {st }}$, this contributed to the global spread of COVID-19 (Báo Điện tử Đài tiếng nói Việt Nam, 2020; Báo Lao động Thủ đô, 2020; Trang tin về dịch bệnh viêm đường hô hấp cấp COVID-19, 2020a, 2020b). Unfortunately, the government and local authorities faced many new challenges to detect new cases of infection in the community. As a result, there have been many strict infection control interventions carried out, such as halting the granting of border gate visas for foreign citizens (except for special cases), implementing strict entry and exit control at all border gates, etc. The Prime Minister also enacted many legal policies to combat COVID-19 in Vietnam (Báo Tuổi Trẻ, 2020b).

Stage 3: Like many countries around the world, on April $1^{\text {st }}$, the Vietnamese government launched a social distancing campaign under Directive No. 16/ATTRACT and required Vietnamese people to reduce their movement in public (except for essential 
activities) and to close all workplaces except those providing essential services and goods (Báo Điện tử Chính phủ Nước Cộng hòa xã hội chủ nghĩa Việt Nam, 2020). In the meeting of the government's Standing Board on COVID-19 prevention on April $6^{\text {th }}$, Prime Minister Nguyen Xuan Phuc emphasized "At this stage, people's adherence to control measures is one of the most important factors to reduce the impacts of the outbreak" (Báo Bộ Nội vụ, 2020). Therefore, whether Vietnam can be successful in the control of COVID19 or not depends on people's behavior to prevent infection by this disease.

It can be seen that, in practical terms, research on COVID-19 prevention is an urgent issue that contributes to the prevention of its spread in the community in Vietnam. However, to the best of our knowledge, studies on COVID-19 conducted by Vietnamese authors have focused mainly on clinical aspects (Le et al., 2020; Nguyen, Nguyen et al., 2020; Phan et al., 2020), the role of socioeconomic factors, the use of social media on risk perception about COVID-19 (Huynh, 2020), healthcare workers' knowledge and attitudes towards COVID-19 (Huynh et al., 2020), and the surveillance and prevention policies to restrict the spread of COVID-19 (La et al., 2020; Nguyen, Hoang et al., 2020). How Vietnamese people respond to this epidemic based on the many unprecedented measures adopted to control its spread remains unclear. Theoretically, studying the status of COVID-19 epidemic prevention, especially the factors that influence this behavior, will help us to have a better understanding of the behaviors that will help people avoid infectious diseases. This theoretical issue will be clarified in the next section.

\section{COVID-19 PREVENTIVE BEHAVIOR AND ITS DETERMINANTS}

According to the protective motivation theory, Roger (1983) used the term "protective behaviors" to refer to the ways individuals respond to potential threats to their health and safety (cited in Clubb \& Hinkle, 2015, p. 337). This term, per se, is different from the so-called protective measures or precautionary measures, which mean the ways provided to help people avoid being exposed to threats. For instance, while some protective measures against COVID-19 indicated by the WHO are hygienic practices, such as social distancing, travel avoidance, etc., people's protective behaviors against COVID-19 may include wearing face masks and/or gloves when going outside, washing hands with water and soap, avoiding crowds, doing sports, etc.

Roger also emphasized the role of factors influencing human preventive behaviors. He proposed that "both individual and environmental factors can provide either encouragement or discouragement for engaging in protective behaviors and that the effects of such factors are mediated by individual cognitive processes" (Roger, 1983, quoted in Clubb \& Hinkle, 2015, p. 337). Therefore, research on preventive behaviors related to airborne diseases (e.g., tuberculosis, SARS, chickenpox, and especially COVID-19) and their determinants is attracting widespread interest because its findings are useful and provide up-to-date information for authorities, public health policy-makers, and healthcare workers to deliver the best practices to control COVID-19. With this in mind, in this theoretical review, the authors focus on factors associated with people's preventive behaviors against COVID-19. 


\subsection{Knowledge and attitudes towards COVID-19}

There have been many studies investigating factors associated with preventive behaviors against COVID-19 by people across the globe during this special time. In particular, the majority of related research is mainly about the correlations among knowledge, attitudes, and practices (KAP) towards COVID-19. For example, in the very early stage of COVID-19 outbreaks in China, Zhong et al. (2020) conducted a crosssectional survey on preventive behaviors of people in Hubei province about three aspects: (i) People's knowledge of clinical symptoms, mode of transmission, and protective measures; (ii) Their confidence that China can win the battle against the COVID-19 virus; (iii) Their implementation of disease prevention. The results show that people who have a good knowledge of COVID-19 and perceive the risk of this infectious disease tend to have a positive attitude, avoid crowded places, and wear masks when leaving their home. This concurs well with other findings (e.g., Haque et al., 2020; Kebede et al., 2020; Nazir \& Rashid, 2020; Wogayehu et al., 2020).

\subsection{Demographic characteristics}

Based on the above-mentioned studies utilizing the KAP survey model, these behaviors are also influenced by many demographic factors (e.g., age, gender, education, occupation, residence type, religion, socioeconomic status, marital status, etc.).

- Age: Many studies have shown the influence of age difference on people's protective behaviors. For instance, young people (age 18-29) are more likely to stay home (as a preventive practice against COVID-19) than middle-aged people and the elderly during the lockdown (Rahman \& Sathi, 2020). Or in Malaysia, people above the age of 50 are less likely to wear face masks (Azlan et al., 2020).

- Gender: Some studies have found that some potentially risky behaviors are related to male gender (Haque et al., 2020; Shahnazi et al., 2020; Zhong et al., 2020). However, some other studies have reported that behaviors regarding COVID-19 preventive measures are not different between men and women (Hussain et al., 2020; Nie et al., 2020; Rahman \& Sathi, 2020; Rong et al., 2020).

- Occupation: There is a difference in implementing prevention among groups of people with different occupations. According to Haque et al. (2020), the unemployed are more likely to be infected than the employed due to the lack of preventive behaviors. University students and the more highly educated portion of the workforce do better than other career groups in terms of COVID-19 prevention (Rahman \& Sathi, 2020; Zhong et al., 2020). Also, people with health-related jobs are better than nonmedical groups in wearing 
masks, washing their hands, and disposing of masks that have become moist or have been worn at least 8 hours (Hussain et al., 2020).

- Education: It is also found that educational background has an impact on people's preventive behaviors. For instance, people with bachelor's or higher degrees performed their preventive practices (such as staying home, washing hands, wearing masks, and maintaining safe distances) better than those with lower degrees of education (Rahman \& Sathi, 2020; Rong et al., 2020; Zhong et al., 2020).

- Religion: Like gender, whether religion has any effect on people's preventive behaviors against COVID-19 is still controversial. In reality, many cases of not doing well in adopting COVID-19 preventive measures are due to public participation in religious activities (Haque et al., 2020; Mubarak, 2020; Shahnazi et al., 2020;).

- Place of current residence: There is also a difference in implementing COVID-19 disease prevention measures among people living in different communities. People who are in pandemic centers (for example, Hubei and Wuhan, China) wear masks and monitor body temperature more often than people of other areas that are not seen as pandemic centers ( Li et al., 2020; Zhong et al., 2020) and urban people do better than rural people in adopting preventive measures (Rahman \& Sathi, 2020).

\subsection{Perception of environmental factors}

It can be seen that most of the studies have focused on examining the correlation between the implementation of preventive measures and demographic characteristics or the knowledge and attitudes towards the disease. However, how environmental factors impact preventive behaviors remains unclear. In a recent study, Ghanbari et al. (2020) demonstrate that knowledge and attitudes towards social distancing policies have a positive effect on the preventive behavior of people in Iran. That effect contributes to a rapid reduction in the number of infections and deaths. However, to the best of our knowledge, the impact of legal policies and social distancing policies on preventive behaviors has not been dealt with in depth.

In summary, studies on factors associated with people's preventive behaviors against COVID-19 have only started quite recently. How are Vietnamese people's preventive behaviors shaped by their knowledge and attitudes towards COVID-19, as well as by their attitudes towards COVID-19 control and prevention policies during the nationwide social distancing campaign launched recently?

To find out the answer, we conducted a cross-sectional survey based on the KAP model to investigate the relationship between COVID-19 preventive behaviors and three factors: demographic characteristics, people's knowledge of COVID-19, and their attitudes towards legal and social distancing policies during the implementation of the 
social distancing campaign in Vietnam. There are three research questions guiding this study, as follows.

- 1 . Are there any differences in the implementation of precautionary measures among Vietnamese people in terms of gender, age, education, occupation, religion, and place of current residence?

- $\quad 2$. Is there any impact of knowledge and attitudes towards COVID-19, protective measures, legal, and social distancing policies on their protective behavior? (Figure 1).

- 3. What are the factors associated with a good adoption of preventive practices?

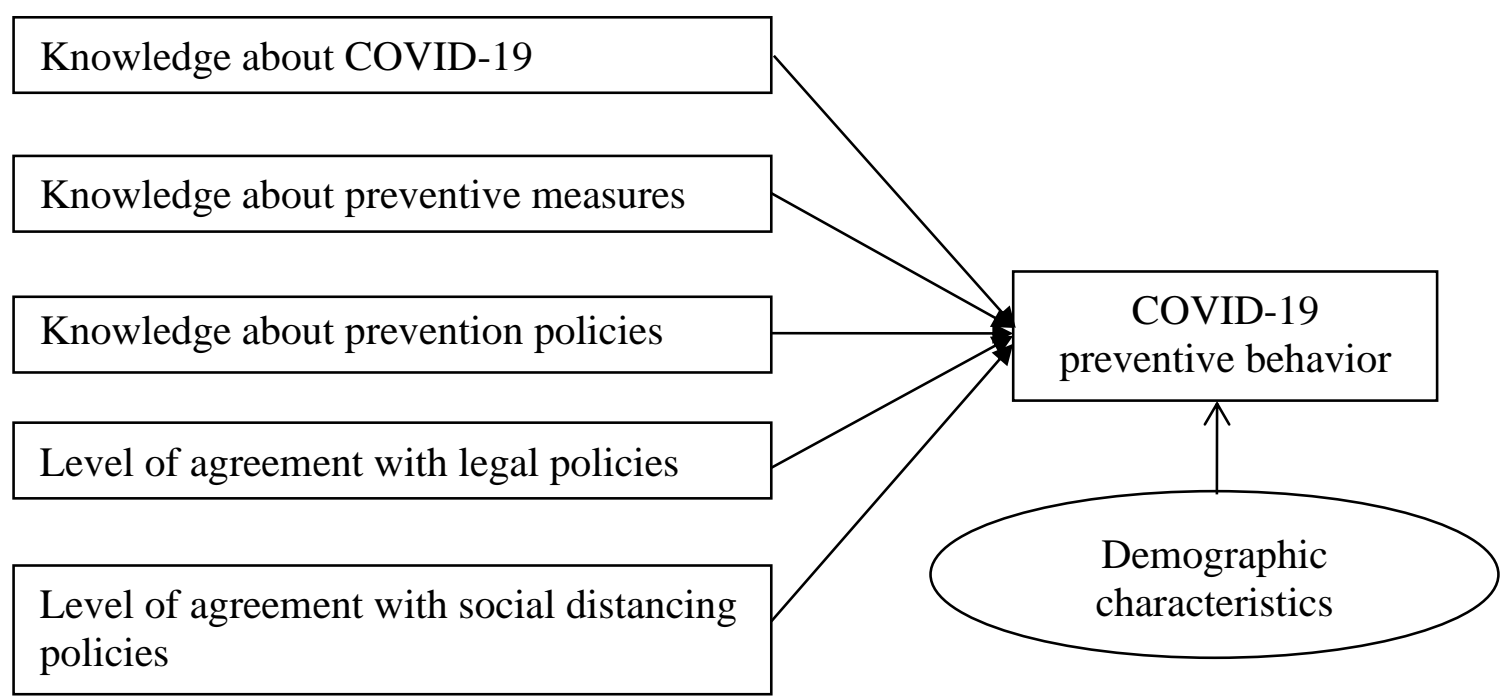

Figure 1. Factors associated with Vietnamese people's preventive behaviors against COVID-19

\section{RESEARCH METHOD}

\subsection{Context of the study}

The cross-sectional study was carried out from April $13^{\text {th }}$ to $15^{\text {th }}, 2020$, i.e., the last three days of the social distancing campaign under Directive No. 16/CT-TTg in Vietnam. Since the country maintained restrictions on movement to minimize community infection risks, using a web-based survey was considered the most feasible method to conduct this community-based study (Ghanbari et al., 2020; Haque et al., 2020; Kebede et al., 2020; Nazir \& Rashid, 2020; Wogayehu et al., 2020; Zhong et al., 2020). This survey relies on the voluntary participation of all eligible respondents who are living in Vietnam. 


\subsection{Data collection instrument}

A self-reported questionnaire was prepared using the Google Drive tool, and the survey link was shared via email, Facebook, Zalo, and other social networks (see https://forms.gle/NLAcSS7fb1X6Uhxv6). In the introduction of this questionnaire, we briefly introduced the background of all the research authors and the aims of this survey. We also asked participants to deliver the survey link to their relatives and friends (if possible) after completing their responses. The results were saved in an anonymous form.

- Survey Questions: The data collection instrument consisted of four parts, including demographic information (i.e., gender, age, education, occupation, religion, and place of current residence), knowledge about COVID-19, attitudes towards legal and social distancing policies, and preventive behaviors against COVID-19.

- $\quad$ Sources of information: All information related to COVID-19 used in the questionnaire was retrieved from the e-book 100 Questions on the COVID19 Precautionary Measures Used in Educational Institutions compiled by the WHO and the Ministry of Education and Training of Vietnam (Phùng, 2020; World Health Organization, 2020a). The information includes the mode and mechanism of transmission, incubation period, clinical symptoms, treatment, and mortality rate. Also, other information related to the policies enacted by the government was collected from the documents, directives, and reports issued by the WHO and the Ministry of Health of Vietnam on their website.

- Survey responses: Respondents' knowledge of COVID-19 was measured by counting the number of selections that participants knew, which was then expressed as a percentage. The level of their knowledge was divided into two classifications: "less interested" $(<70 \%)$ and "interested" $(\geq 70 \%)$. Participants' attitudes towards the policies enacted by the government were assessed using a 5-level Likert scale, in which " 1 " means "slightly agree," and "5" means "highly agree." Then, their attitudes were also divided into two levels: "low agreement" $(<3)$ and "high agreement" $(\geq 3)$. To evaluate the frequency of COVID-19 prevention, we also used a 5-level Likert scale, in which " 1 " is "never" and "5" means "always."

- Reliability: Cronbach's alpha test was run and showed that the reliability coefficients were in the range of 0.605 to 0.862 , all of which are greater than 0.300. As a result, all survey items can be used with a high level of confidence.

\subsection{Participants}

By midnight on April $16^{\text {th }}$, a total of 1,823 participants had completed the questionnaire. After excluding 25 invalid respondents who reported that they were no longer living in Vietnam, the final sample consisted of 1,798 participants. 


\subsection{Statistical analysis}

Microsoft Excel was used for data entry. Then, the data were analyzed using SPSS version 20. Statistical analysis includes a reliability test, descriptive tests, one-way ANOVAs, independent sample t-tests, and simple and multiple linear regressions.

\section{RESULTS}

\subsection{Results of descriptive tests, independent sample t-tests, and one-way ANOVAs}

Table 1. Demographic characteristics and COVID-19 preventive behaviors $(N=1,798)$

\begin{tabular}{|c|c|c|c|c|c|}
\hline Characteristics & & Sample & $\begin{array}{l}\text { Preventive behavior } \\
\text { (Mean } \pm \text { SD) }\end{array}$ & $\mathrm{t} / \mathrm{F} / \mathrm{W}$ & $\mathrm{P}$ \\
\hline \multirow[t]{2}{*}{ Gender } & Male & $481(26.8 \%)$ & $4.67 \pm 0.49$ & & \\
\hline & Female & $1,317(73.2 \%)$ & $4.76 \pm 0.38$ & -4.095 & $0.000 * *$ \\
\hline \multirow[t]{2}{*}{ Religion } & Yes & $512(28.5 \%)$ & $4.70 \pm 0.42$ & & \\
\hline & No & $1,286(71.5 \%)$ & $4.75 \pm 0.42$ & 2.452 & $0.014 *$ \\
\hline \multirow{3}{*}{$\begin{array}{l}\text { Place of } \\
\text { residence }\end{array}$} & Northern Vietnam & $239(13.3 \%)$ & $4.75 \pm 0.44$ & & \\
\hline & Central Vietnam & $1,341(74.6 \%)$ & $4.74 \pm 0.40$ & & \\
\hline & Southern Vietnam & $218(12.1 \%)$ & $4.72 \pm 0.48$ & 0.378 & 0.685 \\
\hline \multirow[t]{3}{*}{ Age } & $<18$ & $117(6.5 \%)$ & $4.73 \pm 0.46$ & & \\
\hline & $19-40$ & $1,593(88.6 \%)$ & $4.74 \pm 0.41$ & & \\
\hline & $>41$ & $88(4.9 \%)$ & $4.76 \pm 0.40$ & 0.207 & 0.813 \\
\hline \multirow{3}{*}{$\begin{array}{l}\text { Educational } \\
\text { setting }\end{array}$} & High school & $122(6.8 \%)$ & $4.68 \pm 0.46$ & & \\
\hline & Post-secondary education & $1,432(79.6 \%)$ & $4.74 \pm 0.42$ & & \\
\hline & Postgraduate education & $244(13.6 \%)$ & $4.76 \pm 0.40$ & 0.513 & 0.220 \\
\hline \multirow[t]{4}{*}{ Occupation } & Unskilled workers & $70(3.9 \%)$ & $4.77 \pm 0.40$ & & \\
\hline & Civil servants & $343(19.1 \%)$ & $4.72 \pm 0.43$ & & \\
\hline & Students & $1,336(74.3 \%)$ & $4.73 \pm 0.42$ & & \\
\hline & Others & $49(2.7 \%)$ & $4.84 \pm 0.23$ & & $0.022 *$ \\
\hline
\end{tabular}

Notes: Others include retirees, tourism attendants, and monks;

(*) indicates the statistic is significant at the 0.050 level and $(* *)$ indicates significance at the 0.010 level.

Descriptive data showed that $481(26.8 \%)$ are male and 3,317 (73.2\%) are female. The majority of respondents are between the ages of 19 and 40 (accounting for $88.6 \%$ ). People living in the northern, central, and southern portions of Vietnam account for $13.3 \%, 74.6 \%$, and $12.1 \%$, respectively. Eighty percent of respondents with bachelor's or higher degrees are students, civil servants, or public employees currently. In this sample, $512(28.5 \%)$ are members of a religion, and 1,286 (71.5\%) are not members of any religion. 
The results presented a statistically significant difference in COVID-19 preventive behavior between men and women $(\mathrm{p}=0.000)$, between those with and without religion $(\mathrm{p}=0.014)$, and among groups of people with different occupations $(\mathrm{w}=0.022)$. In addition, the results of post hoc test analysis showed a difference in preventive behaviors between the group of civil servants and other occupational groups (mean civil servants < mean other; $\mathrm{p}=0.022<0.050$ ) and between the group of students and other occupations (mean students < mean others; $p=0.027<0.050$ ). It means that retirees, tourism attendants, and monks are more likely to perform preventive behaviors better than students and civil servants. In addition, there was no difference in the implementation of COVID-19 prevention among respondents with different places of current residence, age, and educational background ( $p$ > 0.050) (see Table 1).

Table 2. Knowledge and COVID-19 preventive behaviors $(N=1,798)$

\begin{tabular}{llllll}
\hline & Knowledge & Sample & $\begin{array}{l}\text { Preventive behaviors } \\
(\text { Mean } \pm \text { SD) }\end{array}$ & $t$ & $p$ \\
\hline \multirow{2}{*}{ COVID-19 } & Interested & $1,438(80.1 \%)$ & $4.75 \pm 0.40$ & & \\
& Less interested & $358(19.9 \%)$ & $4.67 \pm 0.47$ & -3.003 & $0.003^{* *}$ \\
Precautionary & Interested & $1,548(86.1 \%)$ & $4.77 \pm 0.39$ & & \\
measures & Less interested & $250(13.9 \%)$ & $4.55 \pm 0.51$ & -6.409 & $0.000^{* *}$ \\
& Interested & $859(47.9 \%)$ & $4.79 \pm 0.39$ & & \\
Policies & Less interested & $935(52.1 \%)$ & $4.69 \pm 0.43$ & -5.378 & $0.000^{* *}$ \\
\hline
\end{tabular}

Note: $(* *)$ indicates the value is significant at the 0.010 level.

Descriptive statistics show that more than $80 \%$ of respondents showed considerable concern about COVID-19 and precautionary measures. However, the policies enacted by the government to support the poor and the unemployed had not received much attention from the respondents (47.9\%). Furthermore, the independent sample t-test showed a significant difference in preventive behavior between people who were interested and those who were uninterested in COVID-19 ( $p<0.010)$ (see Table 2).

Table 3. People's attitudes and COVID-19 preventive behaviors $(N=1,798)$

\begin{tabular}{llllll}
\hline & Attitude & Sample () & $\begin{array}{l}\text { Preventive behaviors } \\
(\text { Mean } \pm \text { SD) }\end{array}$ & $t$ & $p$ \\
\hline \multirow{2}{*}{ Legal policies } & Highly agree & $1,795(99.8 \%)$ & $4.73 \pm 0.42$ & & \\
& Slightly agree & $3(0.2 \%)$ & $4.50 \pm 0.87$ & -0.981 & 0.327 \\
\multirow{2}{*}{$\begin{array}{l}\text { Social distancing } \\
\text { policies }\end{array}$} & Highly agree & $1,795(99.8 \%)$ & $4.74 \pm 0.41$ & & \\
& Slightly agree & $3(0.2 \%)$ & $2.94 \pm 1.11$ & -2.800 & 0.107 \\
\hline
\end{tabular}

Table 3 shows that more than $99 \%$ of participants support the recent legal and social distancing policies. Nonetheless, the independent sample t-test indicated no significant difference in COVID-19 preventive behavior between respondents having high and low levels of agreement with these policies $(\mathrm{p}>0.050)$. 


\subsection{Results of linear regression analysis}

\subsubsection{Simple linear regression analysis}

Table 4. Statistical values found in simple linear regression analysis

\begin{tabular}{llllll}
\hline Factors & $\beta$ & $\alpha$ & $R$ & $R_{2}$ & $p$ \\
\hline Knowledge about COVID-19 & 0.031 & 4.560 & 0.105 & 0.011 & $0.000^{* *}$ \\
Knowledge about preventive measures & 0.060 & 4.253 & 0.220 & 0.048 & $0.000^{* *}$ \\
Knowledge about policies used for supporting the poor & 0.029 & 4.580 & 0.146 & 0.021 & $0.000^{* *}$ \\
Level of agreement with legal policies & 0.386 & 2.979 & 0.349 & 0.122 & $0.000^{* *}$ \\
Level of agreement with social distancing policies & 0.311 & 3.400 & 0.382 & 0.146 & $0.000^{* *}$ \\
\hline
\end{tabular}

Note: $(*)$ indicates the statistic is significant at the 0.050 level and $(* *)$ indicates significance at the 0.010 level.

The simple linear regression equations in Table 4 can be written as follows.

- $\quad$ COVID-19 preventive behavior $=4.560+0.031$ (Knowledge about COVID19) $\mathrm{i}+\mathrm{\varepsilon i}$;

COVID-19 preventive behavior $=4.253+0.060$ (Knowledge about preventive measures) $\mathrm{i}+\varepsilon \mathrm{i}$;

- $\quad$ COVID-19 preventive behavior $=4.580+0.029$ (Knowledge about policies used for supporting the poor) $\mathrm{i}+\varepsilon \mathrm{i}$;

- $\quad$ COVID-19 preventive behavior $=2.979+0.386$ (Level of agreement with legal policies) $\mathrm{i}+\mathrm{\varepsilon i}$;

- $\quad$ COVID-19 preventive behavior $=3.400+0.311$ (Level of agreement with social distancing policies) $\mathrm{i}+\varepsilon \mathrm{i}$.

The results showed that all factors presented in Figure 1 influenced respondents' preventive behavior with $\mathrm{p}<0.010$. In addition, from the data in Table 4, it can be interpreted that participants' attitudes towards social distancing and legal policies were the two greatest factors influencing preventive behaviors (with $\mathrm{R}$ values equal to 0.382 and 0.349 , respectively). The sum of all $\mathrm{R}^{2}$ values also indicated that these linear regression models explained $34.8 \%$ of the overall variance in preventive behaviors, which was found to significantly predict the outcome. There could also be other factors that influence preventive behaviors; for instance, gender, religion, place of current residence, age, and educational and occupational background. 
4.2.2. Multiple linear regression analysis

Table 5. Factors associated with a good adoption of preventive practices

\begin{tabular}{lllll}
\hline Variables & $\beta$ & $S E$ & $t$ & $p$ \\
\hline (Constant) & 2.243 & 0.156 & 14.337 & 0.000 \\
Gender & 0.105 & 0.020 & 5.249 & $0.000^{* *}$ \\
Religion & -0.010 & 0.020 & -0.498 & 0.618 \\
Place of residence & -0.003 & 0.018 & -0.195 & 0.845 \\
Age & 0.013 & 0.028 & 0.465 & 0.642 \\
Education & 0.038 & 0.021 & 1.798 & 0.072 \\
Occupation & 0.029 & 0.016 & 1.784 & 0.075 \\
Knowledge about COVID-19 & -0.023 & 0.008 & -2.783 & $0.005^{* *}$ \\
Knowledge about preventive measures & 0.041 & 0.007 & 5.795 & $0.000^{* *}$ \\
Knowledge about policies used for supporting the poor & 0.003 & 0.005 & 0.662 & 0.508 \\
Level of agreement with legal policies & 0.215 & 0.027 & 7.892 & $0.000^{* *}$ \\
Level of agreement with social distancing policies & 0.220 & 0.020 & 10.815 & $0.000^{* *}$ \\
\hline
\end{tabular}

Note: $(*)$ indicates the statistic is significant at the 0.050 level and $(* *)$ indicates significance at the 0.010 level.

The multiple linear regression equations in Table 5 can be written as follows.

- $\quad$ COVID-19 preventive behavior $=2.243+0.15$ (Gender) $\mathrm{i}-0.010$ (Religion) $\mathrm{i}-0.003$ (Place of residence) $\mathrm{i}+0.013$ (Age) $\mathrm{i}+0.038$ (Education) $\mathrm{i}+0.029$ (Occupation) i - 0.023 (Knowledge about COVID-19) i +0.041 (Knowledge about preventive measures) $\mathrm{i}+0.003$ (Knowledge about policies used for supporting the poor) $\mathrm{i}+0.215$ (Level of agreement with legal policies) $\mathrm{i}+$ 0.220 (Level of agreement with social distancing policies) $i+\varepsilon i$

The model significantly predicted the outcome variable, $\mathrm{F}(1786,11)=43.770$, $\mathrm{p}=0.000$, and $21.25 \%$ of the variance in preventive behaviors was explained by this model $\left(\mathrm{R}^{2}=0.212\right)$. Table 5 indicates that gender, knowledge of COVID-19 and preventive measures, and the level of agreement with legal and social distancing policies are factors associated with good adoption of preventive practices. Multiple linear regression analysis showed that females (vs. male, $\beta=0.150 ; p<0.010$ ) having a good understanding of protective measures $(\beta=0.041 ; p<0.010)$ and showing a supportive attitude towards legal policies $(\beta=0.215 ; \mathrm{p}<0.010)$ and social distancing policies $(\beta=0.220$; $\mathrm{p}<0.010)$ tended to have a good adoption of preventive practices. Surprisingly, it was found that if respondents knew more about COVID-19, their adoption of preventive measures may be poorer (approximately $0.02 \%$ of deduction; with $\beta=-0.023 ; \mathrm{p}<0.050$ ) (see Table 5). 


\subsubsection{General conclusion}

There were two steps to find the factors that correlate with a good adoption of preventive practices. In the first step, simple linear regression models were used to examine the extent that five predictor variables (i.e., knowledge of COVID-19, precautionary measures and government support policies, and the level of agreement with legal and social distancing policies) predicted the probability of good preventive behaviors. Secondly, we conducted a multiple linear regression analysis to examine whether all factors mentioned in the first step and some demographic characteristics (such as gender, religion, place of residence, age group, education background, and occupation) could be predictors or not.

The results showed that all variables related to knowledge and attitude significantly predicted the probability of good preventive behaviors. However, in the multiple linear regression analysis, it was indicated that knowledge related to some policies did not show itself to be a predictor variable. In addition, we found that gender impacts respondents' preventive behavior.

\section{DISCUSSION}

\subsection{The impact of demographic characteristics on preventive behavior}

There is no correlation between COVID-19 preventive behavior and some individual factors, such as occupational and educational background, place of residence, and age. However, our results show that the correlation between preventive behavior and gender is statistically significant at a $99 \%$ confidence interval. The impact dimension of the regression coefficient shows that men have worse behaviors in performing epidemic prevention than women. The mean values of the 5-level Likert scale also demonstrate that the implementation of COVID-19 prevention by men is poorer than by women (mean Male $=4.67<$ mean Female $=4.76$ ). Our findings are in line with previous results (e.g., Haque et al., 2020; Shahnazi et al., 2020 Zhong et al., 2020). This finding can be explained by the fact that women tend to take risks less often than men (Pawlowski et al., 2008), that women are more sensitive to negative mental states than men (Zeng \& Zheng, 2018), and that the fearful attitude of females towards the pandemic always scores higher than that of males (Nie et al., 2020). Therefore, as expected, to deal with negative feelings, women are likely to more fully adopt preventive measures than men. It can be seen that because of this tendency, the government and health policy-makers should have given more specific preventive measures for males (Lin et al., 2011; Shahnazi et al., 2020).

Although the regression results show that religion is not a predictor of a good adoption of COVID-19 preventive measures, the results of the t-test show that preventive behaviors between people with and without religion and among people of different professions are not the same. This religion-related finding is in accordance with some studies carried out in several South Asian countries. The implementation of the government's policies has not been effective due to the influence of some religious activities (Haque et al., 2020; Mubarak, 2020 Shahnazi et al., 2020). Therefore, the 
Vietnamese government should pay special attention to religious activities occurring at this time.

\subsection{Correlation between preventive behavior and knowledge about the epidemic situation}

Our findings corroborate the role of knowledge about COVID-19 in people's preventive behavior because t-test results show a statistically significant difference in preventive behavior between people who are interested and uninterested in COVID-19. Our simple and multiple linear regression results also indicate that respondents' preventive behavior is directly proportional to their knowledge about the epidemic situation. Our findings substantiate the results of Nepal et al. (2020) and Nie et al. (2020) and further support the idea that people need to increase their awareness and actions related to COVID-19 prevention.

Unexpectedly, in the multivariate regression analysis, we find that when basic knowledge about COVID-19 increases by one item, the scale of implementing COVID19 prevention will decrease by $0.023 \%$. What is the cause of this paradox? It could be due to the following three reasons. First, despite having a sufficient understanding of the dangers, some may assume that they are not at risk of getting and spreading COVID-19. Second, many people tend to believe that they can have more awareness of and control over the situation. Unfortunately, this belief makes them care less about their behavior. For example, it is known that we must always wash our hands with soap or hand sanitizer after being in crowded places. However, in reality, some may think that if they do not touch any object, hand washing is unnecessary. Third, many respondents may get confused by the information posted on social networks because many unreliable sources were employed to research COVID-19-related information. As a result, the government needs to have specific policies and/or directives to guide people to use social networks as a means to disseminate knowledge more widely to the population and to combat the spread of rumors and misinformation.

Furthermore, in the multiple regression analysis, the results do not show the impact of policies to support the community on preventive behaviors. The reason may be that these policies are not well-known enough by the entire population and that they are merely available for certain groups, such as those who are allowed to receive an allowance, quarantined people, or the unemployed. Indeed, the descriptive statistics show that the number of respondents who are interested in these policies is less than $50 \%$.

\subsection{The impact of attitudes toward government-issued policies on preventive behavior}

The results of the t-test analysis do not show any difference in preventive behaviors between people with high and low consent to government-issued policies (see Table 3). However, from the regression results, it is shown that people's attitude towards these policies plays an important role in having a good adoption of COVID-19 precautionary measures. This means that their good adoption is directly proportional to 
their supportive attitude towards the government's anti-epidemic policies. Therefore, to help Vietnamese people have better preventive behaviors, the government should take anti-epidemic policies and their reasonableness into consideration.

The results in Table 4 also indicate the importance of people's attitudes towards social distancing policies. In essence, social distancing policies have been playing an important role in limiting the spread of COVID-19 in all nations. For example, the growth rate of new cases and deaths from COVID-19 in China and Iran has significantly decreased after the implementation of social distancing (Ghanbari et al., 2020; Shen, 2020). In Vietnam, there were 268 confirmed cases of COVID-19 and zero fatalities as of April 16 ${ }^{\text {th }}$ (Báo Dân Trí, 2020; Báo Tuổi Trẻ, 2020a). Vietnam has been a low-risk area compared to other countries in the same geographic region (e.g., 83,745 cases in China, 10,591 cases in South Korea, 8,100 cases in Japan, 5,223 cases in the Philippines, etc.) (World Health Organization, 2020b). It can be seen that these policies and their reasonableness have been creating a base for building an enormous number of young Vietnamese students' trust in winning the battle against COVID-19, which is considered a strong foundation to help students have good preventive behaviors.

\section{CONCLUSION}

In summary, this cross-sectional study explores the general situation of Vietnamese students' preventive behaviors during the social distancing campaign in the middle of April and indicates several factors associated with their behaviors. It is believed that the consensus between the government and the people can repel any danger, no matter how demanding it is.

However, this cross-sectional online survey was conducted based on a convenience sample that was over-representative of female students. Future research should use a more representative and systematic sampling method to improve the generality of the results. For instance, we should pay more attention to the groups that are vulnerable to the disease, such as unskilled workers and the elderly. Furthermore, our data collection instrument is a self-reported questionnaire. It is possible that participants respond in a positive way to satisfy what they perceive to be expected of them. As a result, studies on preventive behavior assessment should be carried out using other methods, such as telephone interviews, follow-up surveys, etc.

\section{ACKNOWLEDGMENTS}

We gratefully acknowledge the respondents participating in this survey and sincerely thank Tu Phung Ngoc for participating as a content reviewer and translator.

\section{REFERENCES}

Azlan, A. A., Hamzah, M. R., Sern, T. J., Ayub, S. H., \& Mohamad, E. (2020). Public knowledge, attitudes and practices towards COVID-19: A cross-sectional study in Malaysia. PLoS ONE, 15(5), 1-15. 
Báo Bộ Nội vụ. (2020). Thủ tướng: Sự chấp hành của người dân là yếu tố quan trọng nhất. https://moha.gov.vn/tin-tuc-su-kien/diem-tin/thu-tuong-su-chap-hanh-cuanguoi-dan-la-yeu-to-quan-trong-nhat-44032.html

Báo Dân Trí. (2020). Thủ tuớng: Tranh thủ giai đoạn vàng, quyết liệt chống dịch Covid19. https://dantri.com.vn/xa-hoi/thu-tuong-tranh-thu-giai-doan-vang-quyet-lietchong-dich-covid-19-20200316195549954.htm

Báo Điện tử 24H. (2020). Bộ Y tế lý giải vì sao 16 bệnh nhân nhiếm Covid-19 tại Việt Nam đều khỏi bệnh. https://www.24h.com.vn/tin-tuc-trong-ngay/bo-y-te-ly-giaivi-sao-16-benh-nhan-nhiem-covid-19-tai-viet-nam-deu-khoi-benh-c46a1127209. html

Báo Điện tử Chính phủ Nước cộng hòa xã hội chủ nghĩa Việt Nam. (2020). Thủ tướng chi thị: Cách ly toàn xã hội tù 0 giờ $1 / 4$ trên phạm vi toàn quốc. http://baochinhphu.vn/Xa-hoi/Thu-tuong-chi-thi-Cach-ly-toan-xa-hoi-tu-0-gio14-tren-pham-vi-toan-quoc/391485.vgp

Báo Điện tử Đài Tiếng nói Việt Nam. (2020). Việt Nam ghi nhận ca nhiễm Covid-19 thú 17. https://vov.vn/tin-24h/viet-nam-ghi-nhan-ca-nhiem-covid19-thu-17-1018707 .vov.

Báo Lao động Thủ đô. (2020). Kiểm soát chặt việc xuất, nhập cảnh. http://laodongthudo.vn/kiem-soat-chat-viec-xuat-nhap-canh-104611.html

Báo Tuổi trẻ. (2020a). Dịch COVID-19 chiều 15-4: Không ca nhiê̂m mới, 171 người đã ra viện. https://tuoitre.vn/dich-covid-19-chieu-15-4-khong-ca-nhiem-moi-171nguoi-da-ra-vien-20200415180659341.htm

Báo Tuổi trẻ. (2020b). Tù Oh ngày 18-3, tạm ngùng cấp thị thực cho người nước ngoài nhập cảnh Việt Nam. https://tuoitre.vn/tu-Oh-ngay-18-3-tam-ngung-cap-thi-thuccho-nguoi-nuoc-ngoai-nhap-canh-viet-nam-20200317180557605.htm

Caixinwang. (2020). Pneumonia Diary: a pneumonia outbreak in Wuhan. http://www.caixin.com/2020-01-23/101507939.html.

Chen, N., Zhou, M., Dong, X., Qu, J., Gong, F., Han, Y., Qiu, Y., Wang, J., Liu, Y., Wei, Y., Xia, J., Yu, T., Zhang, X., \& Zhang, L. (2020). Epidemiological and clinical characteristics of 99 cases of 2019 novel coronavirus pneumonia in Wuhan, China: A descriptive study. The Lancet, 395, 507-513.

Clubb, A. C., \& Hinkle, J. C. (2015). Protection motivation theory as a theoretical framework for understanding the use of protective measures. Criminal Justice Studies, 28(3), 336-355.

Cổng thông tin điện tử của Bộ Y tế Việt Nam (2020). Cẩm nang hỏi-đáp thông tin về bệnh viêm đường hô hấp cấp do chủng mới vi rút corona (nCov). https://moh.gov.vn/tin-tong-hop/-/asset_publisher/k206Q9qkZOqn/content/camnang-hoi-ap-thong-tin-ve-benh-viem-uong-ho-hap-cap-do-chung-moi-vi-rutcorona-ncov- 
Ghanbari, M. K., Behzadifar, M., Imani-Nasab, M. H., Behzadifar, M., Bakhtiari, A., Mir, I., Wu, J., \& Bragazzi, N. L. (2020). The impact of the social distancing policy on COVID-19 new cases in Iran: Insights from an interrupted time series analysis. Research Square. https://www.researchsquare.com/article/rs-25818/v1

Haque, T., Hossain, K. M., Bhuiyan, M. M. R., Ananna, S. A., Chowdhury, S. H., Ahmed, A., \& Rahman, M. M. (2020). Knowledge, attitude and practices (KAP) towards COVID-19 and assessment of risks of infection by SARS-CoV-2 among the Bangladeshi population: An online cross sectional survey. Research Square. https://www.researchsquare.com/article/rs-24562/v1

Hussain, A., Garima, T., Singh, B., Ram, R., \& Tripti, R. (2020). Knowledge, attitudes, and practices towards COVID-19 among Nepalese residents: A quick online cross-sectional survey. Asian Journal of Medical Sciences, 11(3), 6-11.

Huynh, G., Nguyen, T. N. H, Tran, V. K., Vo, K. N., Vo, V. T., \& Pham, L. A. (2020). Knowledge and attitude toward COVID-19 among healthcare workers at District 2 Hospital, Ho Chi Minh City. Asian Pacific Journal of Tropical Medicine, 13(6), 1-6.

Huynh, T. L. D. (2020). The COVID-19 risk perception: A survey on socioeconomics and media attention. Economics Bulletin, 40(1), 758-764.

Kebede, Y., Yitayih, Y., Birhanu, Z., Mekonen, S., \& Ambelu, A. (2020). Knowledge, perceptions and preventive practices towards COVID-19 among Jimma University Medical Center visitors, Southwest Ethiopia. Research Square, 15(5), $1-15$.

La, V. P., Pham, T. H., Ho, M. T., Nguyen, M. H., Nguyen, P. K. L., Vuong, T. T., Nguyen, T. H. K., Tran, T., Khuc, Q., Ho, M. T., \& Vuong, Q. H. (2020). Policy response, social media and science journalism for the sustainability of the public health system amid the COVID-19 outbreak: The Vietnam lessons. Sustainability, 12(7), 1-27.

Le, V. T., Nghiem, M. N., Bui, T. T. T., Le, T. T. U., Nguyen, T. T. H., Nguyen, T. P. D., Le, N. T. N., Tran, T. T., Dinh, N. H. M., Nguyen, T. P., Tran, T. H., Nguyen, T. T., Thwaites, G., \& Nguyen, V. V. C. (2020). Duration of viral detection in throat and rectum of a patient with COVID-19. https://www.medrxiv.org/content/10. 1101/2020.03.07.20032052v1

Li, W. H., Liu, B., Liu, M., Zhao, X. H., \& Chen, Q. S. (2020). Investigation and analysis of public cognition and prevention awareness of Corona Virus Disease 2019 inside and outside Hubei Province. Journal of Jinan University, 41(2), 186-193.

Lin, Y. L., Huang, L. J., Nie, S. F., Liu, Z. Y., Yu, H. J., Yan, W. R., \& Xu, Y.H. (2011). Knowledge, attitudes and practices (KAP) related to the pandemic (H1N1) 2009 among Chinese general population: A telephone survey. BMC Infectious Diseases, 11(1), 1-9.

Liu, Y. F., Liu, L. N., Wang, Y., Du, X. Y., Ma, H., \& Yao, J. (2020). Clinical course and characteristics of patients with 2019 novel coronavirus disease in Wuhan, China: 
A single-centered, retrospective, observational study. Research Square. https://www.researchsquare.com/article/rs-26427/v1

Mubarak, N. (2020). Corona and clergy: The missing link for an effective social distancing in Pakistan. Time for some unpopular decisions. International Journal of Infectious Diseases, 95, 431-432

Munster, V. J., Koopmans, M., van Doremalen, N., van Riel, D., \& de Wit, E. (2020). A novel coronavirus emerging in China - Key questions for impact assessment. New England Journal of Medicine, 382, 692-694.

Nazir, S. \& Rashid, A. (2020). Knowledge, attitudes and practices among residents of Kashmir towards Covid-19 pandemic. International Journal of Medical Science and Innovative Research, 5(2), 130-135.

Nepal, R., Sapkota, K., Adhikari, K., Paudel, P., Adhikari, B., Paudyal, N., Sapkota, K., $\&$ Nepal, R. (2020). Knowledge, attitude and practice regarding COVID-19 among healthcare workers in Chitwan, Nepal. Research Square. https://www.researchsquare.com/article/rs-26774/v1

Nie, S. N., Cao, J., Tuo, A., \& Zheng, Y. C. (2020). Public's status of KAP for COVID19 and its influencing factors. Shanghai Preventive Medicine. https://pesquisa.bvsalud.org/global-literature-on-novel-coronavirus-2019-ncov/ resource/en/czh-284

Nguyen, M. D., Hoang, D. H., Tran, A. T., Mai, T. L. B., Pham, H. D. \& Pham, M. T. (2020). From first COVID-19 case to current outbreak: A Vietnamese report. Electronic Journal of General Medicine, 17(4), 1-4.

Nguyen, T. H., Nguyen, V. T., Ngo, T. T. H., Nghiem, V. B., Doan, T. B., Phung, T. T. H. \& Nguyen, T. K. A. (2020). Outbreak investigation for COVID-19 in northern Vietnam. The Lancet Infectious Diseases, 20(5), 535-536

Novel Coronavirus Pneumonia Emergency Response Epidemiology Team. (2020). The epidemiological characteristics of an outbreak of 2019 novel coronavirus diseases (COVID-19)-China. China CDC Weekly, 2(8), 113-122.

Pawlowski, B., Atwal, R., \& Dunbar, R. I. M. (2008). Sex differences in everyday risktaking behavior in humans. Evolutionary Psychology, 6(1), 29-42.

Phan, T. L., Nguyen, V. T., Luong, C. Q., Nguyen, V. T., Nguyen, T. H., Le, Q. H., Nguyen, T. T., Cao, M. T., \& Pham, D. Q. (2020). Importation and human-tohuman transmission of a novel coronavirus in Vietnam. The New England Journal of Medicine, 382(9), 872-874.

Phùng, X. N. (2020). 100 câu hỏi - đáp về phòng, chống dịch bệnh covid-19 trong các co sở giáo duc. NXB Bộ Giáo dục và Đào tạo.

Rahman, A. \& Sathi, N. J. (2020). Knowledge, attitude, and preventive practices toward COVID-19 among Bangladeshi internet users. Electronic Journal of General Medicine, 17(5), 1-6. 
Rong, H., Duan, R. \& Chen, X. J. (2020). Study on the rural residents' knowledge, attitude and practice on COVID-19 and their coping styles. Journal of Chengdu Medical College, 1-7. http://kns.cnki.net/kcms/detail/51.1705.r.20200415.0933.002.html

Shahnazi, H., Ahmadi-Livani, M., Pahlavanzadeh, B., Rajabi, A., Hamrah, M. S., \& Charkazi, A. (2020). Assessing preventive health behaviors from COVID-19 based on the health belief model (HBM) among people in Golestan Province: A cross-sectional study in Northern Iran. Research Square. https://www.research square.com/article/rs-24871/v1

Shen, J. F. (2020). Analyzing the determinants of the spread of covid-19 among the provincial regions in China. Research Square. https://www.researchsquare. com/article/rs-26465/v1

Trang tin về dịch bệnh viêm đường hô hấp cấp COVID-19. (2020a). Thưc hiện tốt khoanh vùng, dập dịch để hạn chế lây lan dịch COVID-19 ra cộng đồng. https://ncov.moh.gov.vn/web/guest/-/thuc-hien-tot-khoanh-vung-dap-dich-ehan-che-lay-lan-dich-covid-19-ra-cong-ong

Trang tin về dịch bệnh viêm đường hô hấp cấp COVID-19. (2020b). Rút ngay giấy phép hiệu thuốc tăng giá khẩu trang mà không cần thanh tra. https://ncov.moh.gov.vn/web/guest/-/rut-ngay-giay-phep-hieu-thuoc-tang-giakhau-trang-ma-khong-can-thanh-tra

Wogayehu, B., Taye, W., Chisha, Y. \& Faraja, K. (2020). Knowledge regarding 2019 novel coronavirus (2019-nCoV) infection among final year health science students at Arbaminch College of Health Sciences, Southern Ethiopia: A crosssectional study. Research Square. https://www.researchsquare.com/article/rs$24777 / \mathrm{v} 1$

World Health Organization. (2020a). Coronavirus. https://www.who.int/healthtopics/coronavirus\#tab=tab_3

World Health Organization. (2020b). Coronavirus disease (COVID-19) Situation Report6. https://www.who.int/emergencies/diseases/novel-coronavirus-2019/situationreports.

World Health Organization. (2020c). Coronavirus disease (COVID-19) Situation Report107. https://www.who.int/docs/default-source/coronaviruse/situation-reports/202 00506covid-19-sitrep-107.pdf?

World Health Organization. (2020d). Middle East respiratory syndrome coronavirus (MERS-CoV) - Saudi Arabia. https://www.who.int/csr/don/05-may-2020-merssaudi-arabia/en/

World Health Organization. (2020e). WHO Director-General's statement on IHR Emergency Committee on Novel Coronavirus (2019-nCoV). https://www. who.int/dg/speeches/detail/who-director-general-s-statement-on-ihr-emergencycommittee-on-novel-coronavirus-(2019-ncov).

Zhong, B. L., Luo, W., Li, H. M., Zhang, Q. Q., Liu, X. G., Li, W.T., \& Li, Y. (2020). Knowledge, attitudes, and practices towards COVID-19 among Chinese residents 
during the rapid rise period of the COVID-19 outbreak: A quick online crosssectional survey. International Journal of Biological Sciences, 16(10), 17451752 .

Zeng, Q. \& Zheng, X. F. (2018). The gender difference between conditional acquisition of disgust and fear: An ERPs investigation. Studies of Psychology and Behavior, 16(5), 624-631. 